\title{
Research on the Meaning and Value of the Core Literacy of English Language Disciplines
}

\author{
Yesheng Sun ${ }^{1}$, Xiangying $\mathrm{Tu}^{2}$ \\ ${ }^{1}$ Jiangxi Modern Polytechnic College, Nanchang, Jiangxi, 330095 \\ ${ }^{2}$ Jiangxi Institute of Applied Science and Technology, Nanchang, Jiangxi, 330100
}

Keywords: meaning; value; core literacy; English language disciplines

\begin{abstract}
The core literacy of English disciplines refers to the qualities and abilities that students should be able to adapt to the needs of their lifelong development and social development in the learning of English disciplines. The value of education can be derived from the elements of education-educators, educatees, and education for analysis. From the perspective of the educator, the core qualities of the English discipline can lead teachers in classroom teaching; from the perspective of the educatees, the core qualities of the English discipline can promote students to become a complete person; from the perspective of education, the core qualities of the English discipline can provide an important basis for the selection and determination of course content.
\end{abstract}

\section{Introduction}

In recent years, with the advancement of China's internationalization level and the promulgation of "Opinions of the Ministry of Education on Deepening Curriculum Reform to Implement the Basic Tasks of Lideshuren", the "core accomplishment" has become a hot word in China's education field. In February 2016, the Chinese Association of Education released the "China's Students' Development Core Competencies (Consultation Draft)" and proposed "social responsibility, national identity, international understanding, humanistic heritage, scientific spirit, aesthetic interest, learning to learn, physical and mental health, practice "Innovation" is an essential character and key ability that Chinese students should be able to adapt to the needs of lifelong development and social development. In China, which is still dominated by subjects, it is necessary and major to realize the necessary qualities and abilities of these students. Through the cultivation of core literacy in each discipline, the overall accomplishment of students will be enhanced. English, as a compulsory course for basic education in China, is one of the necessary skills for talent in the 21st century. The essence of English is a communication tool. However, under the pressure of the college entrance examination, the nature of English is alienated. Students only control words, grammatical structures, etc., ignoring the cultivation of listening, speaking, reading, writing, and literacy. Therefore, to clarify the connotation and structure of core English literacy and to clarify its value, we can better guide the teaching of English subjects in the context of comprehensively deepening the curriculum reform and improve the overall core qualities of students.

\section{The Meaning of the Core Accomplishment of English Disciplines}

The cultivation of the core qualities of English subjects has become the current direction of English teaching reform. However, the meaning and structure of the core qualities of English subjects are still ambiguous. This undoubtedly causes confusion for the teaching staff at the source. To understand the meaning of the core qualities of English disciplines, we must first clarify two issues. One is the meaning of the core qualities of students' development. That is, it is necessary to find out what the core qualities are in the end; the other is the core qualities of the discipline and the core qualities of the students' development. In fact, the core accomplishment has been developing in China so far. Its meaning has long been not an issue of debate. Based on the analysis of the core competencies "key competence" and the results of foreign research on core literacy, the "China's 
Students Development Core Literacy" project team proposes that students' development of core qualities means that students should have the ability to adapt to lifelong development. The necessary qualities and key abilities for social development need [1]. We simplified the sentence and found that the so-called core quality is the character and ability. As a complete person, a student has many qualities and abilities that he should possess. However, the qualities and abilities that core literacy refers to are not some simple, basic, freely graspable qualities and abilities. Instead, students are required to adapt. The lifelong development and social development of an individual requires the qualities and abilities that must be possessed by these two major themes.

With regard to the relationship between core literacy of disciplines and core literacy of students' development, the realization of core qualities of students' development is bound to be implemented through subject teaching. Students learn through various disciplines and the integration of disciplines in the synthesis of various disciplines. Under the effect, students will eventually develop core qualities. In other words, there is a relationship between the core literacy of a subject and the development of core qualities of a student. However, this whole is not simply a cumulative patchwork of parts, but is the result of an orderly and rational integration between the parts. This means that we must properly handle the relationship between the discipline's core qualities and the core qualities of students' development, in order to reflect the characteristics and unique values of the disciplines, and ensure the implementation of the students' core qualities. Otherwise, it will easily lead to a clearer separation between disciplines and disciplines. The tendency to merge with international disciplines penetrates the trend [2]. After clarifying the relationship between core literacy and the relationship between core literacy and core competence of student development, we understand the meaning of the core literacy of English disciplines. It is not difficult to find that the so-called core literacy of English disciplines refers to students in the English discipline. The qualities and abilities that should be acquired in the course of study to meet the needs of students' lifelong development and social development are the objectives that English teachers should achieve in teaching, and also the contribution of the English subject to the core qualities of students' development, and also the core qualities of students' development. With this understanding, we can further explore the value of the core literacy of the English discipline, that is, to discuss what it does.

\section{The Educational Value of Core Subjects in English Disciplines}

Under the background of deepening the reform of basic education curriculum, core literacy has become China's curriculum and teaching goal, guiding the continuous deepening of curriculum reform in our country. It is a new type of weapon that we declare war on "knowledge base" after the implementation of quality education. Clarifying the educational value of the core qualities of English subjects can increase the attention of educators to the core qualities of English disciplines. Then, what is the educational value of the core literacy of English disciplines and how should we analyze its educational value? The author believes that the educational value of core literacy in English disciplines can be analyzed from the three dimensions of education elements-educators, educators, and education influences.

From the perspective of educators, the core qualities of English disciplines can lead teachers in classroom teaching [3]. The literacy content we have elaborated above is the goal that English teachers should strive to achieve in teaching. It indicates the direction of English teachers' teaching. Over the past decade or so, we have denounced the various shortcomings of exam-oriented education. Specifically, in the English disciplines, it is typical that dumb English and Chinglish are deeply rooted in students' minds, grammar rules, universal writing templates, and reading comprehension. The problem-solving techniques are all the contents of the teaching of teachers, but they do not notice the communicative and instrumental nature of English as a language. Under the teacher evaluation system where the student's performance is highest, the teacher only teaches the requirements of the syllabus, and the contents outside the syllabus are shelved so that after the students finish the English study at the end of the sixth year and the fourth year of the university, they still cannot achieve and the native English speakers do not have The goal of barrier 
communication is also incapable of reading foreign primary sources. As a result, we held the banner of quality education to declare war on exam-oriented education. We engage in activities and engage in competitions, but we still use fractions to describe heroes. Since we are unable to put forward other specific and explicit goals other than the emphasis on knowledge, teachers are still mastering the teaching process. Knowledge is the main goal, and we have not been able to win in a contest with knowledge-based. The "knowledge-based" education dissociates learning into memory and training. Its core is scores, which completely puts students' subjectivity into one place. Today's core literacy of English disciplines - intercultural communication skills, international understanding, and foreign languages Learning strategies and active learning awareness focus on students' real life and future development. They help students find themselves and develop themselves in the information age. Teachers are freed from words, grammar, and composition to pay attention to students' real life and personality characteristics. It not only clearly points out the necessary qualities and critical abilities that students should cultivate in this discipline of English, but also that these qualities and abilities are indispensable for the development of students' core qualities, so that teachers see the English discipline they teach. The contribution to the overall development of students will lead the teachers to a truly human-oriented education [4].

From the perspective of the educated, the core qualities of the English discipline can promote students to become a complete person. The fundamental purpose of education is to promote the free development of people [5] and make people become complete people. Zhou Guoping, a famous philosopher, believes that education is the formation of a real human being. It is the growth of human spiritual ability and becomes a complete person in the sense of human nature. So what kind of person can be called a complete person? According to Lu Hongming, president of the county school principal Changsha Middle School for 100 years, a complete person does not mean a perfect person or an omnipotent person. Instead, students' abilities in all fields are maximally stimulated. Personality is improved as much as possible. Human development is never-ending, and "the complete person" is a person who can study forever, advance continuously and progress, not a perfect person who has been perfect. ".

It is true that the examination and education of students in pure examination-oriented education has been clearly exposed. They are in urgent need of a good medicine. As stated in this article, the core literacy of English subjects refers to the qualities and abilities that students should receive in the study of English subjects that can be adapted to the lifelong development and social development needs of the students. This is in line with the self-development and lifelong learning in the "completed person". The claim coincides, and it becomes a good medicine to cure students. The physical and mental development of students is not yet mature. Their healthy development requires the correct guidance of teachers. Under the background of cultivation of core literacy, subject teaching carries the character and ability required by students to develop core qualities, and English teachers, based on the curriculum content selected based on core literacy of the discipline aim to develop teaching activities with core literacy as the goal. Promote students to become a flesh-and-blood learner, a complete person, not a test machine. Therefore, for the educated, the core qualities of the English discipline can promote students to become a complete person.

From the perspective of educational impact, core literacy in English disciplines can provide an important basis for the selection and determination of curriculum content. According to Taylor's principle, the next step after the course objectives are determined in course preparation is to select course content. Then, for English, what kind of course content should we choose to ensure the achievement of the core qualities of English subjects? In the past, the main basis for our choice of English course content was the logic of English knowledge, which was basically based on vocabulary, grammar, discourse, topics, functions, and modules. However, as society develops, new knowledge is constantly emerging that represents new expressions of words and expressions. Our textbooks are never able to keep up with the development of the times. As a result, more and more knowledge is available, and the books are getting thicker and thicker. When it is limited, it is really caught up in the dilemma of "borderliness and boundlessness." The value of selected knowledge is also worrying. Today, in this ever-changing era, we are submerged in the ocean of information and 
data, but we endure the thirst of knowledge. The century-long challenge of "What knowledge is most valuable" ushers in new challenges. The core of the English language discipline is just like a buoy light in the sea of English knowledge, which provides a new basis for the selection of English course content. We have a new answer to the century-old question of "What knowledge is most valuable": that is, it is most valuable to promote knowledge that helps students develop the core qualities of the discipline. Therefore, the value of English subject knowledge has a new standard of judgment. Any knowledge that is conducive to cultivating the core literacy of students will become the content of teacher education and student science. In the course content based on core literacy of the discipline, knowledge will be mastered. It is not our ultimate goal. Our ultimate goal is to develop students' intercultural communicative abilities, international acumen, foreign language learning strategies, and active learning awareness through the use of English subject knowledge and subject activities. To "the era of core accomplishment," it is no longer limited to the mastery of subject knowledge, and it is no longer the hero of fractions. Therefore, the core qualities of English disciplines can provide an important basis for the selection and determination of curriculum content.

\section{Conclusion}

The core literacy concept has become the DNA of global education reform. Countries around the world are seizing this idea to carry out curriculum reform, textbook compilation, and teaching innovation. Many educational experts are researching the core literacy contents and the students' core qualities model under the core literacy concept, which also makes different disciplines face the challenges of teaching models and methods. The core qualities have distinctive characteristics of the times. Its proposal makes the world think about the direction of education. How to train students' core competencies in the core literacy to promote the transformation of English teaching in China? This is a challenge for English education in China. We must base ourselves on the local community, combine the international core literacy framework and the student core literacy model, and promote the reform of our English curriculum and teaching according to local conditions. We should take the lead in major education reforms and develop students' core qualities and capabilities.

\section{References}

[1] Zhang Yaxin, Guo Aimin. Design of push-pull air-discharging mechanism in greenhouses [J]. Journal of Chifeng University (Natural Science). 2013 (01)

[2] Xu Yuemin. Technical Research on Urban Lighting District [J]. Talented Intelligence. 2012 (32)

[3] Liu Jun. Electromagnetic Compatibility Design of PCB [J]. Petroleum Instruments. 2012 (01)

[4] Xuan Xuan, Meng Future, Lu Mingxiang. Liaoning Province Agricultural Science and Technology Information Technology Integration and Demonstration [J]. Agricultural Network Information. 2011 (04)

[5] Wang Xinkun, Li Hong. Research status and development trend of greenhouses in China [J]. Journal of Drainage and Irrigation Machinery Engineering. 2010 (02) 